\title{
Access to medicines after TRIPS: Is compulsory licensing an effective mechanism to lower drug prices? A review of the existing evidence
}

\author{
Eduardo Urias ${ }^{1,2,3}$ and \\ Shyama V. Ramani ${ }^{1}$ \\ ${ }^{1}$ UNU-MERIT, Maastricht, The Netherlands; \\ ${ }^{2}$ Athena Institute, VU Amsterdam, Amsterdam, \\ The Netherlands; ${ }^{3}$ Elabora Consultoria, \\ São Paulo, Brazil \\ Correspondence: \\ E Urias, UNU-MERIT, Maastricht, The \\ Netherlands \\ e-mail: urias@merit.unu.edu
}

\begin{abstract}
While Trade-Related Aspects of Intellectual Property Rights (TRIPS) was expected to hike up prices of patented medicines, there was no consensus on its likely final impact on access, because the agreement housed instruments to address this challenge. For instance, compulsory licensing, through the facilitation of price reductions, was considered to be an important countermeasure. However, little is known about the extent to which compulsory licensing has actually been effective in reducing prices of muchneeded patented drugs. To fill this gap, this paper undertakes a systematicreview of the existing evidence on the impact of compulsory licensing on drug prices. Retrieval and analysis of 51 observations of pre- and post-compulsory licensing prices indicate that a compulsory licensing event is likely to reduce the price of a patented drug, albeit with some caveats. Moreover, compulsory licensing procurement from the international market is likely to be more effective in reducing drug prices than contracts to local companies. These findings are reconfirmed in the race to improve access to Remdesivir for hospitalized COVID-19 patients. Clearly, the future incidence and impact of compulsory licensing will depend on further possible procedural refinements to ease its implementation, the development of technological and manufacturing capabilities in developing countries, and the importance of biologics among life-saving drugs.

Journal of International Business Policy (2020) 3, 367-384. https://doi.org// 0.1 057/s422/4-020-00068-4
\end{abstract}

Keywords: compulsory licensing; access to medicines; intellectual property protection; systematic review; pharmaceutical industry

\section{INTRODUCTION}

Patent protection gives market exclusivity to inventors. Such a monopolistic position usually translates into higher prices as compared to those that would prevail under competitive market settings. Consequently, the patented commodity becomes unaffordable to more consumers. Moreover, when the product in question is essential to human health, such as medicines, the issue
Received: 10 January 2019

Revised: 3 July 2020

Accepted: 28 July 2020

Online publication date: 3 September 2020 
of patenting itself becomes contentious. This debate with respect to medicines has been further intensified since 1995, when the international agreement on Trade Related Aspects of Intellectual Property Rights (TRIPS) became effective. While it was universally acknowledged that TRIPS would hike up the prices of patented medicines, there was no consensus on its likely final impact on access. This was because TRIPS also included multiple instruments to promote access, such as issue of compulsory licenses, parallel imports, and incentivization of technology transfer (Scherer \& Watal, 2002). So the moot question is: are these instruments sufficient to ensure adequate access to lifesaving patented drugs in case of need? In an attempt to provide elements for a partial answer to this question, in this paper, we examine the role of compulsory license implementation as a means to lower the prices of patented medicines and thereby improve their access.

Before the TRIPS Agreement, approximately 40 countries had forbidden patent protection for pharmaceutical products and/or processes (Boulet et al., 2000). Under this scenario, low-price copies of medicines developed by research-based pharmaceutical companies could be exported to international markets without the permission of the patent holders. However, one of the main requirements of TRIPS is that all member nations have "to make patents available for any inventions, whether products or processes, in all fields of technology without discrimination, subject to the normal tests of novelty, inventiveness and industrial applicability". The agreement also sets 20 years as the minimum period of patent protection in all World Trade Organisation (WTO) member nations and prohibits discrimination between domestic and imported products. Thus, as all WTO signatory countries are required to grant patent protection of pharmaceutical products and processes, TRIPS effectively removed the possibility for generic manufacturers to reverse-engineer pharmaceutical process in order to produce and sell medicines at lower prices.

At the same time, TRIPS contains flexibilities that could be utilized to alleviate the negative impact of patents on access to pharmaceutical products, especially in low- and middle-income countries. For instance, developing countries that did not provide product patent protection for pharmaceuticals or any other knowledge intensive products when the TRIPS Agreement came into force could delay patent protection for those products until
January 2005. Also, initially, least-developed countries (LDCs) had up to 1 January 2006 to adjust their intellectual property rights (IPR) systems. In November 2005, the transitional period for LDCs was extended to 1 July 2013, and, in June 2013, it was further shifted to 1 July 2021. Specifically with respect to pharmaceutical patents, in 2002, the TRIPS Council pushed the period for LDCs to comply to 2016. In the latest decision in this regard, in 2015, the TRIPS Council stipulated that the key provisions of the TRIPS Agreement would not apply to pharmaceutical products in LDCs until January 2033 (WTO, 2015). This decision also keeps open the option for further extensions beyond that date.

Besides these flexibilities, the TRIPS Agreement includes the use of various instruments to improve access to medicines. Among these is the right of member states to grant compulsory licenses. A compulsory license is a license issued by a government of a country to a third party to produce a patented medicine without the patentee's permission. Article 31 of the TRIPS agreement allows the issuance of a compulsory license under circumstances such as 'national emergencies', 'other circumstances of extreme urgency', 'public noncommercial use', or against 'anti-competitive' practices (WTO, 2006). This means that a member country can improve access to a particular patented medicine through making an exception to its existing patent without entering into a price negotiation with the patent holder.

Originally, compulsory licensing was to be used predominantly for the purposes of supplying the domestic market of the country in which the license was issued. This, however, posed a problem for countries that did not have sufficient manufacturing capacity to produce their own generic pharmaceuticals and, therefore, had to rely on imports of medicines. In November 2001, the Declaration on the TRIPS Agreement and Public Health (also known as Doha Declaration) recognized that member states with insufficient or no technological capacity in pharmaceuticals could face difficulties in making effective use of compulsory licensing under the TRIPS Agreement.

Following the Doha Declaration, in 2003, the TRIPS Council made a first formal attempt, referred to as the 'August 30 Decision', to allow for exports under compulsory licenses to countries with no technological capacity to produce the drugs they needed. Two years later, on 6 December 2005, the August 30 Decision became permanent through 
insertion of Article 31bis after Article 31 and an Annex to the TRIPS Agreement after Article 73. The August 30 Decision ratified the 'Paragraph 6 system' allowing the use of compulsory licensing to exclusively export to countries that could not produce the medicines themselves due to a lack of technological capacity. This system was formally built into the TRIPS Agreement after acceptance of the Protocol amending the TRIPS Agreement by twothirds of the WTO in 2017. This was the first time that the WTO accords were amended since the organization opened in 1995.

Compulsory licensing is often advocated as the main alternative to circumvent the potential negative impact of patents on access to medicines. For instance, a scoping review of the literature on how access to medicines can be improved under the current IPR system set by the TRIPS Agreement shows that compulsory licensing is the most advised TRIPS safeguard to improve access to medicines (Urias, 2015). Although lack of access to medicines is often associated with low- and middle-income countries, compulsory licensing of high-priced pharmaceuticals is also part of the policy agenda of high-income countries. For instance, in 2015, as the Veterans Administration stopped treating new hepatitis $C$ patients due to lack of funds, Senator Bernie Sanders requested the Veterans Affairs Secretary to issue compulsory licenses for the patents of Sofosbuvir, which was costing about US\$1000 per tablet at the time (Sanders, 2005). Also, in 2017, the German Federal Court of Justice confirmed a compulsory license granted for an antiretroviral drug for people living with HIV/AIDS, and the Minister for Health of the Netherlands announced his intention to explore the use of compulsory licensing for highly expensive medicines (Cappuyns \& Vanherpe, 2018).

Nonetheless, little is known about the extent to which the existing experiences with compulsory licensing have been effective in improving access to medicines. In this article, we aim to fill this gap by conducting a systematic review and analysis of the existing evidence on the impact of compulsory licensing on drug prices. Through an in-depth analysis of existing qualitative and quantitative data retrieved from selected studies, we hope to develop a deeper evidence-based understanding of the impact of compulsory license issuance on affordability.

\section{A FRAMEWORK FOR COMPULSORY LICENSING}

By its very definition, the issuance of a compulsory license implicates three main actors:

- the government that issues the license;

- a third-party licensee which can import, manufacture, use, and/or sell copies of the patented medicine; and

- the patentee which is entitled to compensation (i.e., royalties) - often a research-based pharmaceutical company.

In Figure 1, we present the decision process involved in the use of compulsory licensing to improve access to medicines. As the focus of this article is on the impact of compulsory licensing on drug affordability, we start with the assumption that there are pharmaceutical products currently unaffordable due to patents $^{1}$. Such drugs are the focus of the paper.

To improve access, some patent holders voluntarily license their products to generic manufacturers. This is done either through direct contractual arrangements between patent holders and generic manufacturers or through mechanisms such as the Medicine Patent $\mathrm{Pool}^{2}$. However, it is relatively common for voluntary licenses to restrict the geographical territories where the licensed product can be commercialized. If there is no voluntary license for a given drug or a country is not included in a given voluntary license territory, then compulsory licensing can be a viable option for some countries under certain circumstances to improve access to patented medicines. At the outset, we must distinguish between LDCs and the rest.

Let us start by considering a non-LDC country, say country A, which requires a branded drug. Its public agency will first explore if there are alternative suppliers of the corresponding generic, either national firms or international generic producers. If national firms have no capacity or inadequate capacity, and there are no international generic producers, the outcome with or without a compulsory license is bound to be sub-optimal. However, in case national firms are wanting in technological and manufacturing capabilities, and there is an additional international source, say from country $\mathrm{B}$, two actions are required for a transaction through issue of compulsory licensing. Country A must issue a compulsory license to import the drug, and country B must issue a compulsory license, under the Paragraph 6 system discussed in the previous section, to export the drug to country A. In other words, both the government of the non- 


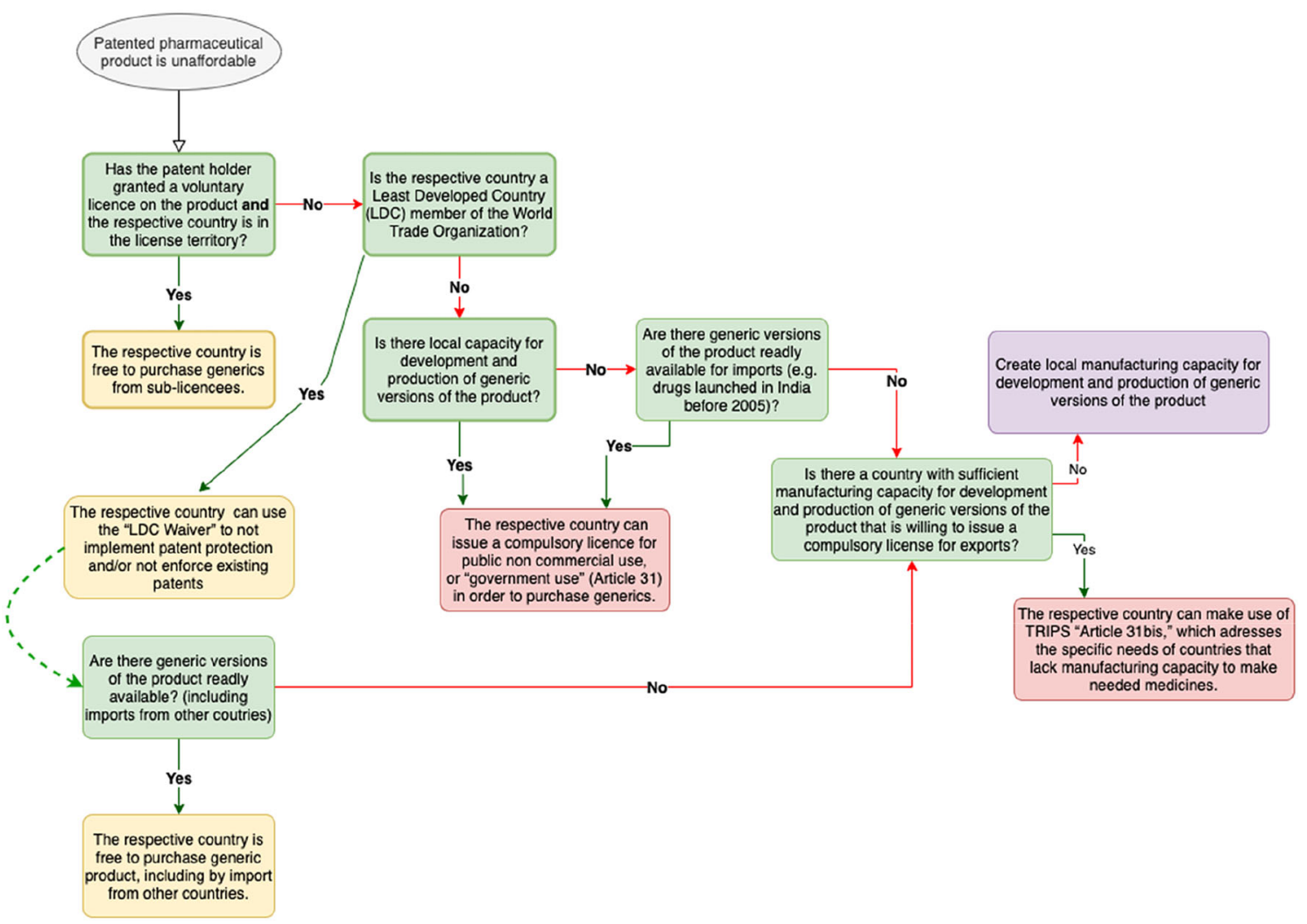

Figure 1 Compulsory licensing flow chart for countries. Source Adapted from Medicines Law and Policy (2017).

LDC country demanding the generic and the government of the country supplying the generic must issue a compulsory license.

In addition to the requirements of compulsory licenses being issued by two countries in order to engage in trade of a branded drug, other binding IPR constraints linked to the scope of the license issued by the original innovator must be satisfied. For instance, if the pharma firm in the exporter country firm B is a licensee or sub-licensee of a drug patent, and if this license excludes country A, then the potential exporter firm in country B cannot sell to country A, even if both countries issue a compulsory license. Therefore, independently of the compulsory licenses themselves (in the importing and exporting countries), other IPR constraints on distribution must also be taken into account to enable access via trade.

Turning now to the LDCs, it is to be noted that LDC members of the WTO have until January 2033 to implement patent protection or to enforce existing patents of pharmaceutical products. This means that, whenever an LDC needs a branded drug, it can use the "LDC Waiver" and simply import the cheapest available generic of the drug from the international market (provided they have the financial resources to do so) without resorting to compulsory licensing. On the other hand, if there are no generic versions readily available for imports, it can apply the Paragraph 6 system to, say, country B to newly manufacture a generic version. Then, in this case, country B has to issue a compulsory license for exports.

This double compulsory licensing imposed by TRIPS matters, because it makes non-LDC countries' access to other international generic producers in the global South more difficult. For instance, India was a major generics supplier in the international market during the 1990s, and this industrial prowess had a dramatic impact on access to medicines, especially for HIV/AIDS patients in the developing world (Ramani \& Mukherjee, 2014).

Then, when India signed the TRIPS agreement, a 'mailbox' provision was included in its intellectual property rights framework. According to this provision, patent applications for medicines would be examined only after 2005, when the TRIPS treaty would be in force. The delay between the date of application and the actual examination and issuance of patent constrained the ability of the patent applicant to institute infringement actions against 
generic manufacturers (Gervais, 2003; Hason \& Shimotake, 2006). This is because, for any patent granted under the mailbox provision, the patent holder could not initiate a patent infringement action against a company that was producing and manufacturing the corresponding product (Gervais, 2003; Hason \& Shimotake, 2006).

In other words, between 1995 and 2005, if a patent had been granted to a product, the respective patent holder would only be entitled to receive 'reasonable royalty' from the manufacturers of generic drugs (Kale \& Little, 2007). For instance, in 2003, the Swiss-based company Novartis was awarded an Exclusive Marketing Rights (EMR) for the drug Glivec (imatinib mesylate), for which a patent application had been received in 1997 under the mailbox provision (Ecks, 2008). However, even after the EMR ruling, three Indian generic manufacturers were still allowed to manufacture and export this drug (Ecks, 2008). Because of this mailbox provision, many drugs patented in India between 1995 and 2005 have affordable generic versions available worldwide, as Indian generic companies were able to continue to produce and export them, as long as they paid royalties to the patent holder(s) (Babovic \& Wasan, 2011; Guennif \& Ramani, 2012; Kale \& Little, 2007). So, it is important to note that, from 2005, the rules of the game and the playing field itself changed, and this was mostly related to the end of the transitional period for India to become TRIPS-compliant.

Therefore, after 2005, Indian firms have been able to develop generic versions of pharmaceutical products only if voluntary licenses are granted to them by the patent holders, or after patent expiration of the original branded drug or if Indian courts reject evergreening patents. The latter occurred in some cases of antiretrovirals like Tenofovir disoproxil fumarate, Darunavir, and Atazanavir sulfate. Thus, given the inability of Indian firms to develop and to sell either at home or in international markets, drugs patented in India after January 2005 cannot be made available to a country, unless both the Indian government and the country's government are willing to issue a compulsory license for export and import, respectively.

\section{METHODOLOGY}

\section{Systematic Reviews of Literature}

A literature review can be a research method in its own right and its format varies depending on its purpose (Jesson et al., 2011). Petticrew and Roberts (2008) have defined a systematic literature review as a "A method of making sense of large bodies of information, and a means to contributing to the answers to questions about what works and what does not" (p. 2). Therefore, it is an appropriate method to assess the effectiveness of compulsory licensing based on the existing evidence.

Systematic reviews typically involve comprehensive search strategy with the goal of identifying, appraising, and synthesizing all relevant studies on a particular topic (Uman, 2011). Jesson et al. (2011) argue that a systematic approach for literature reviews comprises the definition of a clear stated purpose, a question, a defined search approach, stating inclusion and exclusion criteria, and producing a qualitative appraisal of articles

\section{Search Approach}

This systematic review was conducted in accordance with the Preferred Reporting Items for Systematic Reviews and Meta-Analysis (PRISMA) statement (www.prisma-statement.org). A comprehensive search was performed in the bibliographic databases Web of Knowledge, PubMed, and Scopus. The final search was performed on 9 November 2018 without date or language restrictions. Search terms included controlled terms as well as free text terms. The following terms were used (including synonyms and closely related words) as index terms or free-text words: 'compulsory license and 'pharmaceuticals', 'medical', 'health,' 'drug', or 'treatment'. The full search strategies for all databases can be found in the Supplementary Information.

After removing duplicates, 425 articles were included for title and abstract screening. These studies were imported into Covidence, which is an online software to assist systematic reviews. All the studies were reviewed by both authors for relevance based on titles/abstracts and full text. Disagreements were resolved through discussion to reach consensus.

\section{Inclusion Criteria}

In order to delimit the final set of studies to be included in this systematic review, four main eligibility criteria were applied. First, a compulsory licensing event was defined as an instance of actual granting of such a license by a government authority. Therefore, studies that focused on cases wherein a compulsory license was considered, but not actually issued (as a consequence, for instance, of a donation, a voluntary license, or price 
reductions), were excluded from this review. Second, only studies on compulsory licensing event of medicines after the TRIPS Agreement became effective in 1995 were included. Thus, compulsory licensing of other types of goods, or instances that took place prior to TRIPS, were excluded. Third, as the objective of this review is to evaluate the impact on prices, only studies containing information on product prices before and after the compulsory license being issued were considered eligible for this review. Fourth, only original peer-reviewed studies were included. This means that opinion papers, editorials, letters, and gray literature in general were excluded from this review. However, it is important to mention that several eligible studies had collected their data from non-peer-reviewed, gray, and legal literature, which minimizes any bias against these types of sources.

\section{Data Extraction and Analysis}

Data were extracted using a pre-designed form including fields such as: Country; Year; Drug; Brand; Manufacturer; Disease; Price before compulsory license; Price after compulsory license; Comparison with international prices; Source type (civil society report; industry report, official document, or academic publication); Compulsory license for local production (Yes/No), and Exporter country (if applicable).

The data on prices were, therefore, extracted from the studies included in the review. As these studies were not at all similar, the combination of the data in a meta-analysis was simply not possible (Jesson et al., 2011). Alternatively, a thematic analysis was carried out and a narrative and tabular synthesis based on descriptive statistics was applied to derive the main results.

\section{RESULTS}

\section{Study Selection}

A PRISMA flow-diagram shows the selection of papers for inclusion and exclusion (Figure 2). In total, 86 articles have been considered eligible for full-text analysis. Of these, 15 articles were included in this study.

Table 1 summarizes the number of events, countries, and drugs covered in the final corpus of articles. As shown in Table 1, Beall et al. (2015) retrieved the most compulsory licensing events $(n=17)$, followed by Mohara et al. (2012) $(n=7)$, Thanitcul and Braslow (2013) $(n=4)$, and Ford et al. (2007) $(n=3)$. Four studies analyzed two compulsory licensing events each, whereas seven studies analyzed a single event each.

\section{Characteristics of the Compulsory Licensing Events}

In our review, we found 24 compulsory licensing events in eight countries (Brazil, Ecuador, India, Indonesia, Thailand, Malaysia, Rwanda, Zimbabwe) for which prices before and after the compulsory licensing were available (see Table 2).

The 24 compulsory licensing events covered 16 different drug formulations, among which the following were the object of multiple compulsory licensing events: Lamivudine + Zidovudine $150 \mathrm{mg}+300 \mathrm{mg} \quad(n=3), \quad$ Efavirenz|600 mg' $(n=3), \quad$ Lamivudine + Nevirapine + Zidovudine $150 \mathrm{mg}+200 \mathrm{mg}+300 \mathrm{mg}(n=2)$, and Atazanavir sulfate|150 $\mathrm{mg}(n=2)$. Most of them were to treat HIV/AIDS $(n=11)$. The other drug formulations are to treat cancer $(n=4)$ and cardiovascular diseases $(n=1)$.

In terms of price comparisons, the studies retrieved in this research gathered 51 observations of prices before and after compulsory licensing events (see Table 3). The compulsory licensing of Sorafenib in India $(n=8)$, Efavirenz $600 \mathrm{mg}$ in Brazil $(n=7)$, and Efavirenz $600 \mathrm{mg}$ in Thailand $(n=6)$ are the events reported most often in the literature. Furthermore, price information for 9 out of the 24 compulsory licensing events were reported only once. Of the 51 data points on prices, only 23 are based on official documents from Governments and/or companies. Other source types include civil society reports $(n=9)$, industry reports $(n=6)$ and academic publications $(n=4)$. No source was reported in 9 cases. In terms of compulsory licensing events, 13 out of the 24 identified events reported official governmental documents as data source.

\section{Impact on Prices}

The impact on prices is summarized in Table 4, and its examination leads to the following inferences.

\section{Result 1: Issuance of Compulsory Licensing or a Compulsory Licensing Event is Likely to Reduce Prices of Patented Drugs}

From Table 2, the mean price reduction ranges between 66.2 and $73.9 \%$, if we take, respectively, the minimum or the maximum price variation reported in the literature. The price reductions after 


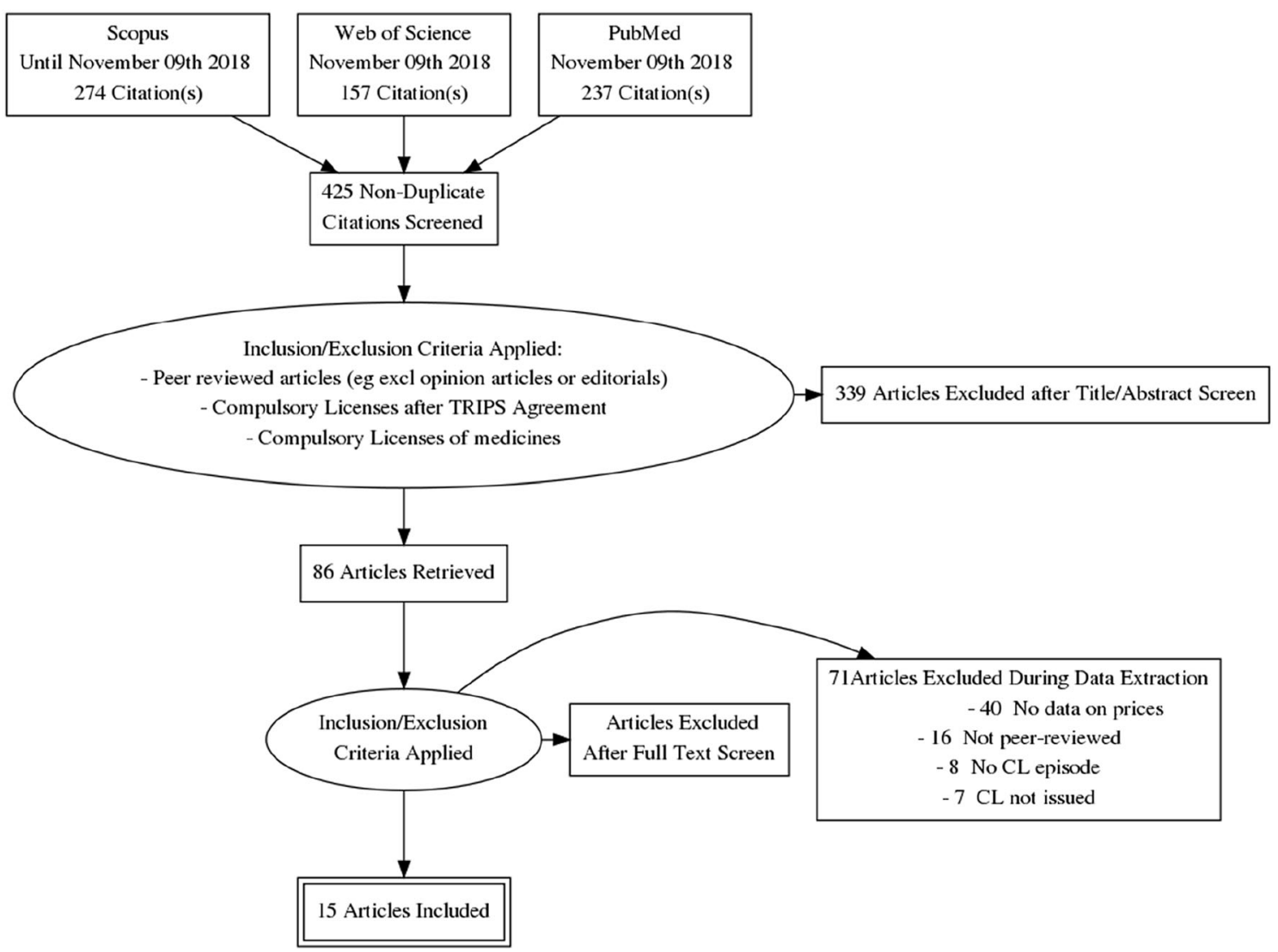

Figure 2 PRISMA flow-diagram.

compulsory license events range from 6.7\% [Atazanavir sulfate in Brazil (2007)] to 98\% [Lamivudine + Nevirapine + Zidovudine (2004)]

Having noted the above, we again recall that a meta-analysis was not conducted because prices across events are not comparable due to many context-specific factors affecting the final price after a compulsory license (e.g., market structure, out-of-pocket payments, technological capacity). Also, there was often no information about the price point (e.g., list price, price at dispensation) being used in each study included in this review. However, for each compulsory licensing event identified in this review, it is reasonable to assume that prices pre- and post-compulsory licensing refer to the same price point, which makes the comparison of relative price change across events less problematic.

\section{Result 2: However, the Existing Public Knowledge on the Degree of Price Drop is Imperfect}

Indeed, in the articles that specify the prices before and after, there are contradictions regarding the degree of price drop following an event. For instance, Beall et al. (2015) presented two compulsory licensing events for Atazanavir sulfate in Brazil, based on industry reports, However, Ramani and Urias (2018), relying on official documents and interviews with Brazilian authorities, show that the compulsory licensing for Efavirenz in 2007 was the only compulsory licensing event in that country. Indeed, according to the latter's findings, there was no compulsory license for Atazanavir sulfate in Brazil. The price reduction (mis)reported by Beall et al. (2015) as a compulsory licensing event is, in fact, a discount given by the manufacturer of the original drug after a compulsory license threat (Ramani \& Urias, 2018). If these compulsory licensing events are removed from our sample, then the lowest price reduction resulting from a compulsory license is $15.6 \%$ [Malaysia Lamivudine + Zidovudine (2003)].

Similarly, the price before the compulsory licensing of Lamivudine + Nevirapine + Zidovudine|by the Canadian authorities is reported as US\$20.00 in Beall et al. (2015) (source type industry report) and US\$0.39 in Stirner \& Thangaraj (2013) (source type civil society report), an extreme difference greater than $5000 \%$. None of studies included in 
Table 1 Compulsory licensing events per study retrieved

\begin{tabular}{|c|c|c|c|}
\hline $\begin{array}{l}\text { Study } \\
\text { no. }\end{array}$ & Authors (no. of events covered & Country & Drug(s) \\
\hline 1 & Beall et al. (2015) $(n=17)$ & $\begin{array}{l}\text { Brazil } \\
\text { Ecuador } \\
\text { Indonesia } \\
\text { Malaysia } \\
\text { Rwanda } \\
\text { Thailand } \\
\text { Zimbabwe }\end{array}$ & $\begin{array}{l}\text { Atazanavir sulfate|150 mg } \\
\text { Efavirenz|600 mg } \\
\text { Abacavir + Lamivudine|600 mg + } 300 \mathrm{mg} \\
\text { Lopinavir + Ritonavir|100 mg + } 25 \mathrm{mg}, 200 \mathrm{mg}+50 \mathrm{mg} \\
\text { Ritonavir|100 mg } \\
\text { Lamivudine| } 600 \mathrm{mg} \\
\text { Lamivudine + Nevirapine + Zidovudine } 150 \mathrm{mg}+200 \mathrm{mg}+300 \mathrm{mg} \\
\text { Lamivudine + Zidovudine|150 mg + } 300 \mathrm{mg} \\
\text { Nevirapine| } 200 \mathrm{mg} \\
\text { Didanosine|100 mg, } 250 \mathrm{mg} \\
\text { Zidovudine|100 mg }\end{array}$ \\
\hline 2 & Ford et al. (2007) $(n=3)$ & Brazil & $\begin{array}{l}\text { Efavirenz|600 mg } \\
\text { Lopinavir + Ritonavir|200 mg + } 50 \mathrm{mg}\end{array}$ \\
\hline 3 & Ramani and Urias $(2018)(n=1)$ & Brazil & Efavirenz|600 mg \\
\hline 4 & Rodrigues and Soler (2009) $(n=1)$ & Brazil & Efavirenz|600 mg \\
\hline 5 & Saroha et al. (2015) $(n=2)$ & $\begin{array}{l}\text { Brazil } \\
\text { India }\end{array}$ & $\begin{array}{l}\text { Efavirenz|600 mg } \\
\text { Sorafenib }\end{array}$ \\
\hline 6 & $\begin{array}{l}\text { Stirner and Thangaraj (2013) } \\
(n=2)\end{array}$ & $\begin{array}{l}\text { India } \\
\text { Rwanda }\end{array}$ & $\begin{array}{l}\text { Sorafenib } \\
\text { Lamivudine + Nevirapine }+ \text { Zidovudine } 150 \mathrm{mg}+200 \mathrm{mg}+300 \mathrm{mg}\end{array}$ \\
\hline 7 & Mohara et al. (2012) $(n=7)$ & Thailand & $\begin{array}{l}\text { Clopidogrel bisulfate } \\
\text { Docetaxel } \\
\text { Efavirenz|200 mg } \\
\text { Efavirenz|600 mg } \\
\text { Erlotinib } \\
\text { Letrozole } \\
\text { Lopinavir + Ritonavir|200 mg + } 50 \mathrm{mg}\end{array}$ \\
\hline 8 & Thanitcul and Braslow (2013) & $\begin{array}{l}\text { Thailand } \\
\text { Thailand } \\
\text { Thailand } \\
\text { Thailand }\end{array}$ & $\begin{array}{l}\text { Clopidogrel bisulfate } \\
\text { Efavirenz| } 600 \mathrm{mg} \\
\text { Erlotinib } \\
\text { Letrozole }\end{array}$ \\
\hline 9 & Bognar et al. (2016) & $\begin{array}{l}\text { India } \\
\text { Thailand }\end{array}$ & $\begin{array}{l}\text { Sorafenib } \\
\text { Letrozole }\end{array}$ \\
\hline 10 & Chakrabarti (2015) & India & Sorafenib \\
\hline 11 & Konde (2016) & India & Sorafenib \\
\hline 12 & Manu (2015) & India & Sorafenib \\
\hline 13 & Prasad and Babu (2013) & India & Sorafenib \\
\hline 14 & Raju (2017) & India & Sorafenib \\
\hline 15 & Oh (2006) & $\begin{array}{l}\text { Malaysia } \\
\text { Zimbabwe }\end{array}$ & $\begin{array}{l}\text { Lamivudine + Zidovudine } 150 \mathrm{mg}+300 \mathrm{mg} \\
\text { Lamivudine + Zidovudine } 150 \mathrm{mg}+300 \mathrm{mg}\end{array}$ \\
\hline
\end{tabular}

this review provide detailed information about the price component (e.g., landed price, wholesale selling price, retail price, or dispensed price).

Result 3: Moreover, After the Compulsory Licensing, Procurement from the International Market is More Effective in Achieving Price Reductions than Contracts to Local Companies

Recalling the second section, after issuing a compulsory license, the public agency can either procure the concerned branded drug from the international market or from local firms with the requisite technological and manufacturing capabilities. Let us consider the import possibility. It is noteworthy that the mean price reduction of imported medicines under compulsory licensing $(n=15)$ ranges between 67.1 and $79.4 \%$, depending on whether we consider, respectively, the minimum or the maximum price variation reported in the literature. If the two misreported compulsory licensing events for Atazanavir sulfate in Brazil are removed from the sample, then the price variation range increases, from 71 to $85.2 \%$. Then, turning to the local production option, the 
Table 2 Compulsory licensing events

\begin{tabular}{|c|c|c|}
\hline Country (no. of events) & Year & Drug \\
\hline \multirow[t]{3}{*}{ Brazil $(n=3)$} & 2007 & Efavirenz|600 mg \\
\hline & 2003 & Atazanavir sulfate|150 mg \\
\hline & 2007 & Atazanavir sulfate|150 mg \\
\hline \multirow[t]{3}{*}{ Ecuador $(n=3)$} & 2010 & Lopinavir + Ritonavir|100 mg + 25 mg \\
\hline & 2010 & Ritonavir|100 mg \\
\hline & 2012 & Abacavir + Lamivudine $600 \mathrm{mg}+300 \mathrm{mg}$ \\
\hline India $(n=1)$ & 2012 & Sorafenib \\
\hline \multirow[t]{4}{*}{ Indonesia $(n=4)$} & 2004 & Lamivudine|600 mg \\
\hline & 2004 & Lamivudine + Nevirapine + Zidovudine $\mid 150 \mathrm{mg}+200 \mathrm{mg}+300 \mathrm{mg}$ \\
\hline & 2004 & Lamivudine + Zidovudine $\mid 150 \mathrm{mg}+300 \mathrm{mg}$ \\
\hline & 2004 & Nevirapine|200 mg \\
\hline \multirow[t]{4}{*}{ Malaysia $(n=4)$} & 2003 & Didanosine|25 mg \\
\hline & 2003 & Didanosine|100 mg \\
\hline & 2003 & Lamivudine + Zidovudine $150 \mathrm{mg}+300 \mathrm{mg}$ \\
\hline & 2003 & Zidovudine $100 \mathrm{mg}$ \\
\hline Rwanda $(n=1)$ & 2008 & Lamivudine + Nevirapine + Zidovudine $150 \mathrm{mg}+200 \mathrm{mg}+300 \mathrm{mg}$ \\
\hline \multirow[t]{7}{*}{ Thailand $(n=37)$} & 2006 & Clopidogrel bisulfate \\
\hline & 2006 & Efavirenz|600 mg \\
\hline & 2007 & Docetaxel \\
\hline & 2007 & Erlotinib \\
\hline & 2007 & Letrozole \\
\hline & 2007 & Lopinavir + Ritonavir|200 mg + 50 mg \\
\hline & 2010 & Efavirenz|600 mg \\
\hline
\end{tabular}

mean price reduction of drugs manufactured locally after a compulsory license $(n=10)$ ranges from 65 to $66.8 \%$ due to the discrepancies found in the reported price variations. Interestingly, for the compulsory license of Efavirenz in 2017 in Brazil, the drug was initially supplied by an Indian generic manufacturer until a local consortium could start production. So, for this single compulsory licensing event, there are data on prices for both the imported and the locally produced version of the licensed drug, with the former being lower than the latter.

\section{DISCUSSION}

\section{On the Role and Limitation of Compulsory Licenses to Improve Access}

The utility of compulsory licensing threats as a tool to reduce drug prices in negotiations with patent holders is widely acknowledged (Beall \& Kuhn, 2012; Ramani \& Urias, 2015; Urias, 2015). However, the effectiveness of the actual granting of compulsory licenses on drug affordability is usually assumed rather than substantiated by real evidence. To provide further insight, this systematic review gathered and studied data on price changes brought about through the issuance of compulsory licensing. Our evidence strongly suggests that compulsory licensing is indeed an effective mechanism to achieve price reductions of patented medicines. There are, however, three caveats.

First, only two studies compared the prices obtained after a compulsory license to the international prices of the same drugs (Beall et al., 2015; Ramani \& Urias, 2018). Thus, in most cases, it was not possible to infer to what extent these licenses delivered the best outcome possible, in terms of improving the affordability of patented medicines vis-à-vis the lowest global price.

Second, there are studies demonstrating that alternative approaches, such as price negotiations (with compulsory licensing threats, if needed) and voluntary licensing agreements, can be more effective than the actual issuance of compulsory licenses (Beall et al., 2015; Raju, 2017; Ramani \& Urias, 2018; Urias, 2015). For instance, Ramani and Urias (2018) compare the prices of Efavirenz $600 \mathrm{mg}$ produced in Brazil after a compulsory licensing in 2007 to the lowest international price of a generic equivalent. They show that, in 2009, when the local production of Efavirenz started, this medicine was 2.6 times more expensive than the cheapest generic version. In 2013, this difference climbed to 6.3. Therefore, from a public health perspective, the 
Table 3 Number of observations on prices per compulsory licensing events by the type of source

\begin{tabular}{|c|c|c|c|c|c|c|}
\hline Country and drugs & $\begin{array}{l}\text { Academic } \\
\text { publication }\end{array}$ & $\begin{array}{l}\text { Industry } \\
\text { report }\end{array}$ & $\begin{array}{c}\text { Civil society } \\
\text { report }\end{array}$ & $\begin{array}{c}\text { Official } \\
\text { document }\end{array}$ & $\begin{array}{l}\text { No } \\
\text { data }\end{array}$ & Total \\
\hline Brazil & 1 & 2 & & 3 & 3 & 9 \\
\hline Atazanavir sulfate| $150 \mathrm{mg}$ & & 2 & & & & 2 \\
\hline Efavirenz|600 mg & 1 & & & 3 & 3 & 7 \\
\hline Ecuador & & & 1 & 2 & & 3 \\
\hline Abacavir + Lamivudine $600 \mathrm{mg}+300 \mathrm{mg}$ & & & 1 & & & 1 \\
\hline Lopinavir + Ritonavir|100 mg + $25 \mathrm{mg}$ & & & & 1 & & 1 \\
\hline Ritonavir|100 mg & & & & 1 & & 1 \\
\hline India & & & 1 & 5 & 2 & 8 \\
\hline Sorafenib & & & 1 & 5 & 2 & 8 \\
\hline Indonesia & & & 4 & & & 4 \\
\hline Lamivudine|600 mg & & & 1 & & & 1 \\
\hline Lamivudine & & & 1 & & & 1 \\
\hline \multirow{2}{*}{\multicolumn{7}{|c|}{$\begin{array}{l}+ \text { Nevirapine + Zidovudine } \mid 150 \mathrm{mg} \\
+200 \mathrm{mg}+300 \mathrm{mg}\end{array}$}} \\
\hline & & & & & & \\
\hline Lamivudine + Zidovudine $150 \mathrm{mg}+300 \mathrm{mg}$ & & & 1 & & & 1 \\
\hline Nevirapine|200 mg & & & 1 & & & 1 \\
\hline Malaysia & & & & 4 & 1 & 5 \\
\hline Didanosine $25 \mathrm{mg}$ and $100 \mathrm{mg}$ & & & & 2 & & 2 \\
\hline Lamivudine + Zidovudine $\mid 150$ mg + 300 mg & & & & 1 & 1 & 2 \\
\hline Zidovudine|100 mg & & & & 1 & & 1 \\
\hline Rwanda & & 1 & 1 & & & 2 \\
\hline Lamivudine + & & 1 & 1 & & & 2 \\
\hline \multirow{2}{*}{\multicolumn{7}{|c|}{$\begin{array}{l}\text { Nevirapine + Zidovudine| } 150 \\
\mathrm{mg}+200 \mathrm{mg} \\
+300 \mathrm{mg}\end{array}$}} \\
\hline & & & & & & \\
\hline Thailand & 3 & 1 & 2 & 9 & 3 & 18 \\
\hline Clopidogrel bisulfate & & & & 1 & 1 & 2 \\
\hline Docetaxel & & & & 2 & & 2 \\
\hline Efavirenz|200 mg and $600 \mathrm{mg}$ & 2 & & 1 & 3 & & 6 \\
\hline Erlotinib & & & & 1 & 1 & 2 \\
\hline Letrozole & & & 1 & 1 & 1 & 3 \\
\hline Lopinavir + Ritonavir|200 mg + 50 mg & 1 & 1 & & 1 & & 3 \\
\hline Zimbabwe & & 2 & & & & 2 \\
\hline Lamivudine + Zidovudine $\mid 150 \mathrm{mg}+300 \mathrm{mg}$ & & 2 & & & & 2 \\
\hline Total & 4 & 6 & 9 & 23 & 9 & 51 \\
\hline
\end{tabular}

local procurement strategy after compulsory licensing issuance was not the most favorable to enabling price reduction.

Third, both these approaches to improve access, i.e., compulsory licensing and voluntary licenses, have their own limitations. The use of compulsory licensing as a price negotiation tool is mostly restricted either to drugs that are not protected by patents in India or to countries where there is sufficient local technological and productive capacity to produce pharmaceutical products (Ramani \& Urias, 2015). Similarly, the effectiveness of voluntary licensing is often hampered by geographical or economic limitations and other restrictive licensing terms imposed by pharmaceutical companies (Gold \& Morin, 2012; 't Hoen et al., 2011). For instance,
China, Russia, Thailand, and Brazil are often excluded from voluntary licensing agreements under the Medicine Patent Pool (Luca, 2015).

Beyond price reduction, compulsory licensing can also be legitimized as an instrument of industrial policy to create local manufacturing capacity. Indeed, when the patent holder does not lower prices sufficiently, and is not willing to grant voluntary licenses, then compulsory licensing is the only option. That said, when a license is contracted out to local firms, the price reduction may not be maximal as the local firms need to catch-up in terms of technological and manufacturing capabilities as compared to an international generics producer selling it at a lower price. Although this could be perceived as a sub-optimal 
choice from a public health perspective in the short term, in the long term, it may be a relevant strategy to increase the bargaining power of countries when negotiating prices with patent holders. However, when compulsory licensing is issued for local production, it is important to track prices of licensed drugs over time, and more longitudinal studies are necessary to assess the long-term impact on access to medicines.

\section{On the Impact of TRIPS on the Incidence of Compulsory Licensing}

The caveats with respect to the impact of compulsory licensing along evoked in the previous section, in conjunction with the three central global trends detailed below, raise doubts on the possible use of compulsory licensing by developing countries (not developed ones) to improve access to medicines in the future.

First, currently, the position of 'pharmacy of the developing world' is vacant for many drugs. In the majority of the cases included in this review, after the compulsory licensing event, the drug was imported from India (in 14 of the 24 events). By cross-checking the cases included in this review with the findings of Chaudhuri et al. (2010), we noted that, at the time of the respective compulsory licensing events, there were generic versions available in India for 15 out of the 16 drug formulations identified in this study. The only exception was the compulsory license authorized by the Indian government in 2012 for the drug Sorafenib. In this event, the Indian Controller of Patents authorized the Indian generic manufacturer Natco to produce and supply to the domestic market a generic version of the drug priced at US\$175 per patient per month. At the time, this represented a $97 \%$ reduction from the price being charged by Bayer in India. However, since India became TRIPS-compliant in 2005, Indian generic drug manufacturers cannot produce and sell any generic version of drugs patented there.

Second, the protocol for implementation of compulsory licensing dissuades its application in developing countries. In our review, besides India, the only other country to provide a generic version of a branded drug was Canada. In Rwanda in 2008, a Canadian generic manufacturer was authorized to export Lamivudine + Nevirapine + Zidovudine to the country. To this date, this has been the first and only use of the Paragraph 6 system, which allows for compulsory licensing of essential medicines for exports. This single application of Paragraph
6 has raised several concerns on its practical value. Some authors argue that this mechanism is too complex to work in practice, and it generates additional costs to both buyers and manufacturers (Chami \& Wasswa-Kintu, 2011; Gehl Sampath, 2005; Hannah, 2011).

In Figure 1 (Section 2), we illustrated that, in the absence of voluntary licensing agreements and of generics readily available for imports, the Paragraph 6 system can be the only option for countries without or with insufficient manufacturing capabilities. Thus, given the limitations of the Paragraph 6 system, and the fact that most of the drugs invented after 2005 are protected by patents in India, we can infer that, under the current international IPR system, ceteris paribus, compulsory licensing is likely to play a more limited role in the future.

Third, even emerging countries do not have technological capabilities in biotechnology-based drugs of the future. Increasingly, the drugs are being founded on modern biotechnology rather than synthetic chemistry. These drugs are commonly referred to as "biologics". In 2017, biologics accounted for about $26 \%$ of worldwide pharmaceutical sales (Diependaele et al., 2018). Although biologics make up only a small proportion of the drug market based on the volume of physical units, the expenditure on them is significant in both developed and developing countries because of their high prices (Dowlat et al., 2016). This naturally affects the availability of these biologics to the patients, due to the increasingly burning question of health care financing. The higher price of biologics compared to small-molecule drugs has resulted in a significant burden for patients, health insurers, and public entities supporting medical costs (Chung, 2017). This is hampering access to those essential medicines in both high and lowincome countries. At present, developing country firms do not have technological capabilities to manufacture most of these drugs and developed country firms are not incentivized to produce generic versions. Hence, unsurprisingly, our review does not contain any compulsory licensing event for a biologic drug.

\section{The Race to Improve Remdesivir to Address the Covid-19 Challenge}

The main findings of this paper have been illustrated almost presciently under the corona virus siege. Remdesivir is an antiviral therapeutic produced by the pharma major Gilead Sciences. 


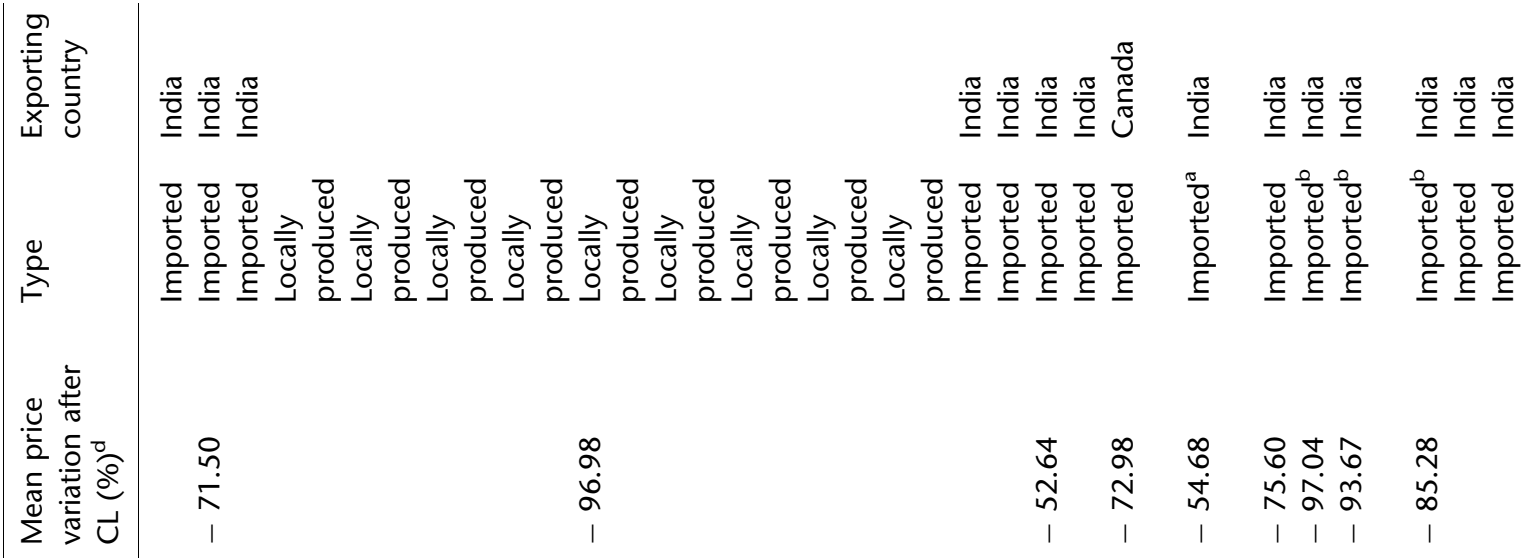

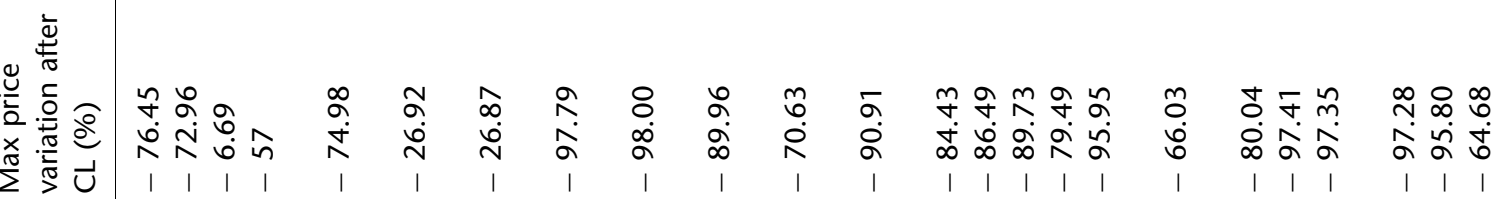
迹

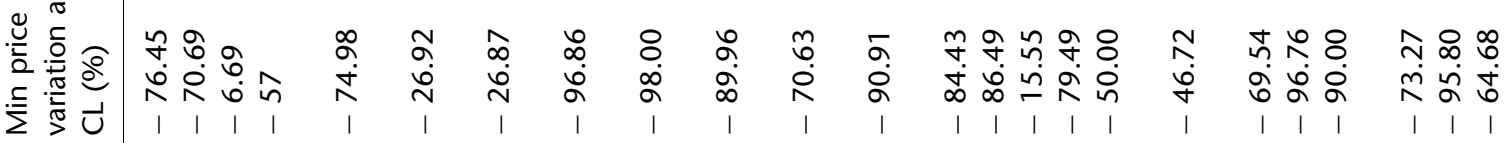
$\stackrel{\mathscr{c}}{\frac{\tilde{m}}{\mathrm{~m}}}$

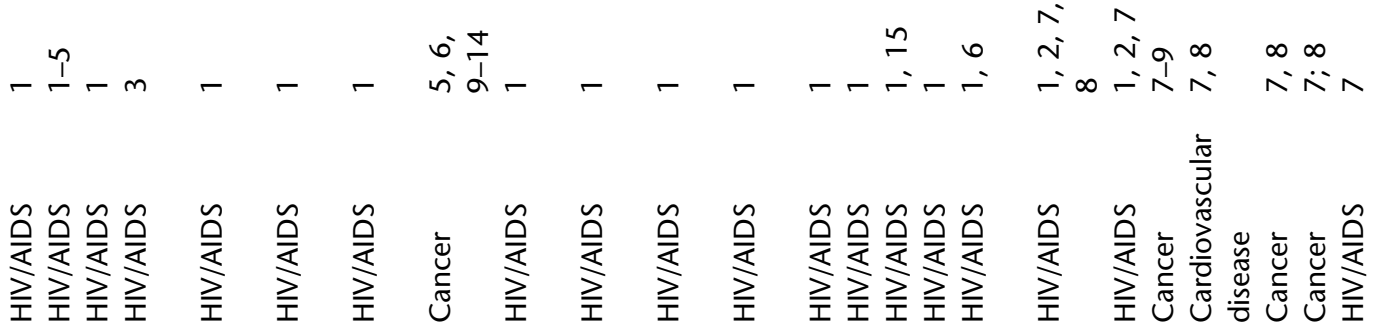

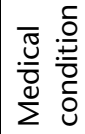
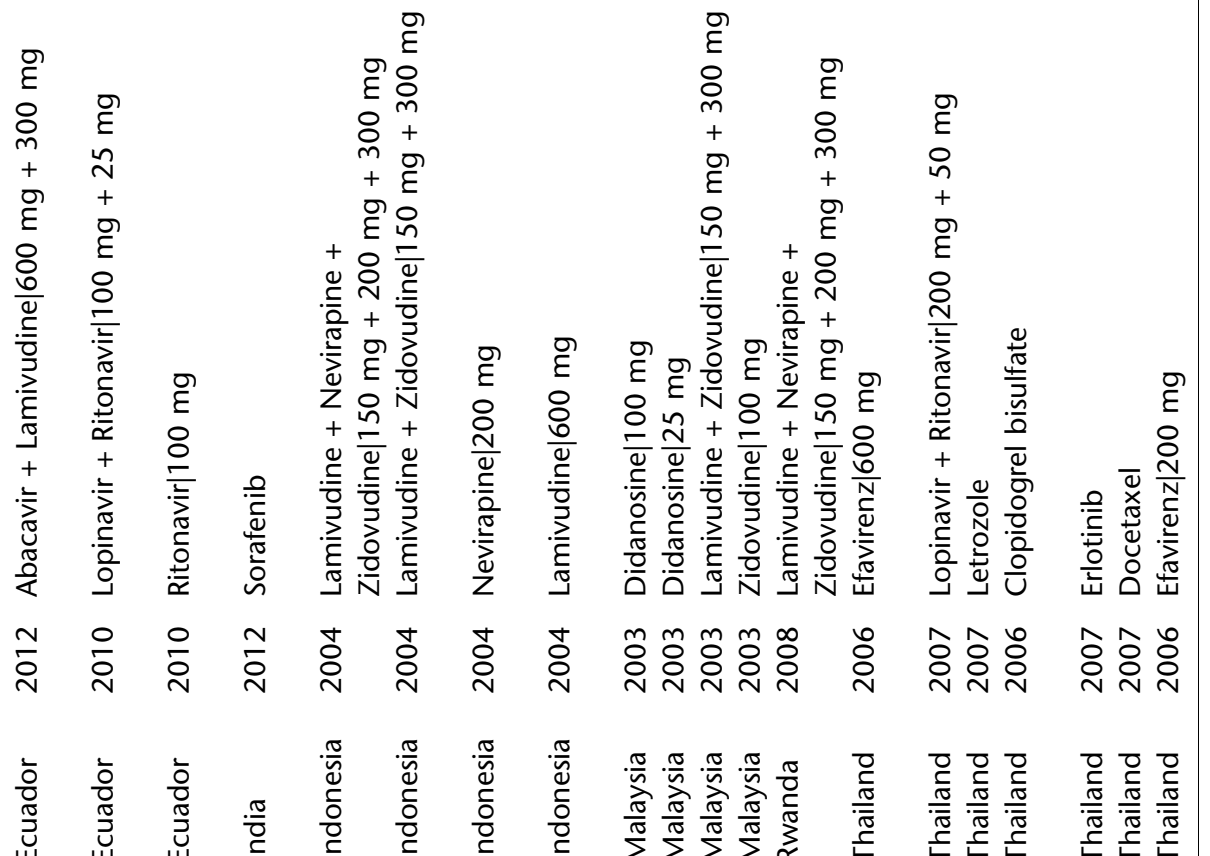

芒客客宫

ำ

$\stackrel{\circ}{\stackrel{\circ}{i}}$

$$
\text { ำ }
$$

¿ 
Administered intravenously to hospitalized patients, it is designed to stop or interrupt viral replication. Though not confirmed fully, clinical trials in Japan and the USA indicated that it can help shorten hospital stays. Following this finding, it was approved by regulatory authorities in the US and Japan for emergency use authorization (EUA) to treat hospitalized COVID-19 patients (Rees, 2020). Remdesivir is priced at $\$ 2340$ per patient (for a 5-day treatment) in developed countries, while its costs have been estimated to be $\$ 5-\$ 10$ per patient (Boseley, 2020; 't Hoen, 2020b).

Compulsory licensing is also considered an important tool by developed countries when crisis hits them

Although compulsory licensing is a TRIPS flexibility that is often perceived as the main mechanism to facilitate increased access to patented pharmaceutical products in developing countries under the coronavirus siege, only developed countries moved fast towards facilitating compulsory licensing.

As soon as Remdesivir was approved by the regulatory authorities, the Trump administration ordered the purchase of about 90\% of Gilhead's targeted production in July, August, and September, leaving very little for the rest of the world. Some countries, such as Canada, France, Germany, and Israel, also acted to improve access to vaccines, drugs, and other technologies, such as diagnostic kits, devices, and supplies, among others ('t Hoen, 2020a).

Canada enacted the COVID-19 Emergency Response Act as a law on 25 March, allowing the Canadian state to produce, sell, and use a patented invention. This act goes both above and around compulsory licensing. Under the new law, the production license can be issued without first negotiating with the rights holder or having local manufacturing ability, but the patentee must be compensated. The law is to be revoked when the crisis is over (Houldsworth, 2020). Similarly, France passed a new law (No. 2020-290) on 23 March, whereby, under article L.3131-15, the Prime Minister can practice price control and launch generics to address the health crisis before expiry of the patent (Loi n²020-290 d'urgence pour faire face à l'épidémie de covid-19, 2020). Germany passed the Prevention and Control of Infectious Diseases in Humans Act on $28 \mathrm{March}$, permitting the issuance of compulsory licensing.

Israel issued a compulsory license on 18 March to get an HIV/AIDS antiretroviral called Kaletra, a combination of the antiviral drugs lopinavir and 
ritonavir developed by AbbVie. Again, although its positive impact on COVID-19 patients is unconfirmed, the patent for Kaletra expires in Israel only in 2024, while it has already expired in other countries, including India, where it has offices.

These acts confirm that changes in national legislation that allow for flexibilities to apply to patent protection, especially compulsory licensing, are an important means to promote quick access to treatment options under crisis situations (OECD, 2020).

\section{Compulsory licensing can be averted through voluntary licensing}

Following Figure 1, the important patent holders concerned have initiated voluntary licenses. Gilead has given voluntary licenses for Remdesivir production to three Indian companies, Cipla Ltd, Hetero Labs Ltd, and Jubilant Lifesciences, with a strong knowledge/technology capability base in antiretrovirals, the Pakistani pharmaceutical company, Ferozsons Laboratories, and the multinational Mylan Labs (Anglo-European). The agreement between Gilead and Mylan allows the latter to manufacture and distribute Remdesivir in 127 low- and middle-income countries, including India (Rees, 2020). However, it is not clear which countries the Indian and Pakistani companies can supply according to the license with Gilead, as about 73 countries and territories including 30 lowand middle-income countries are excluded from the licensing agreement (Baker, 2020). At any rate, the international price cannot be paid by developing country patients.

\section{Addressing COVID-19 and future pandemics via compulsory licensing will depend upon bargaining versus collaboration}

Currently, there is no vaccine to protect against the virus, and nor are there effective pharmaceutical treatments approved for this specific condition. Although existing drugs, including inexpensive generics, are being tested against Covid-19, the ultimate solution for this pandemic seems to rely on the research, development, production, and global distribution of a novel - and potentially patented - vaccine. Therefore, it is extremely important to consider how novel technologies yet to be developed can be made available globally.

What does this augur for compulsory licensing? The answer is unclear. On the one hand, governments must do whatever is needed to fight the pandemic, and safeguarding public health is a legitimate reason to justify the use of compulsory licensing. In spite of this, it can be noted that none of the developing and emerging countries have issued compulsory licensing to access Remdesivir. On the other hand, the possibility of compulsory licensing in developed regions, such as the European Union, China and the United States, may undermine private investments in $R \& D$. Because compulsory licenses can be issued unilaterally, their wider use as an instrument to fight the COVID-19 pandemic may have undesired effects on $R \& D$, as it may lower incentives that IPRs create for innovation (OECD, 2020).

To reconcile these two antagonistic forces, and to promote access, there is an urgent need for global collaboration, discussion on criteria for public funding, and upfront agreements on access and affordability with those engaged in the development of new medical technologies. Alternative mechanisms, such as a possible international advance market commitment (OECD, 2020) or the COVID-19 Technology Access Pool launched by WHO (Medicines Law \& Policy, 2020), could provide an alternative to patent-based incentives for innovation, and eventually reduce the need for compulsory licensing.

\section{LIMITATIONS OF STUDY}

In our study, we could identify only 24 compulsory licensing events for which data were available on prices before and after the event. However, The TRIPS Flexibilities Database developed by Medicines Law \& Policy reports 74 compulsory licensing events of medicines since the TRIPS Agreement came into force. Unfortunately, this database does not include information about prices. Thus, our systematic review provides only a partial description of the real impact on prices. This also shows that there is room for more research in this particular field, as the existing scientific literature does not report on prices of more than two-thirds of the known compulsory licensing events to date.

Also, it was not possible to undertake a statistical meta-analysis of the impact of compulsory licensing on prices using the available information. This method requires that the interventions be very similar so that the 'outcome measure' can be compared. However, there are many context-specific factors affecting the final price after a compulsory license even when comparing the same drug formulations. For instance, market structure, outof-pocket payments, and technological capacity 
among other factors are likely to influence price outcomes. Moreover, as reported in the Results, in the included studies, price data were obtained from a wide variety of sources with varying degrees of credibility, and there was no information available on the price component stages.

\section{POLICY IMPLICATIONS}

Our review highlights the following policy challenges for developing countries which need to be addressed with respect to compulsory licenses to improve their effectiveness with respect to access to medicines for improved health status. Their resolution can then be interpreted as our policy recommendations.

First, the absolute majority of compulsory licensing events retrieved in this review refer to drug formulations to treat HIV/AIDS $(n=19)$. The predominance of compulsory licensing events for HIV/ AIDS drugs is not a surprise. The provisions of compulsory licensing in the TRIPS Agreement use terms like 'national emergency' or 'circumstances of extreme urgency' that are often associated with public health crisis caused by contagious diseases. Furthermore, the Doha Declaration, which was influenced by a context of crisis over access to HIV/AIDS treatment in the developing world, specifies HIV/AIDS, tuberculosis, malaria, and other epidemics as particular diseases of concern. Therefore, the higher incidence of non-communicable diseases in the low- and middle-income countries brings important challenges in terms of improving access to medicines, and compulsory licensing should definitively remain a legitimate alternative for this goal. As our results show, compulsory licensing provisions are equally applicable and useful for non-communicable diseases. This has also been reported in a recent compilation of compulsory licensing attempts (Son \& Lee, 2018). For that, developing countries have to implement adequate local IPR frameworks that allow them to make effective use of such flexibilities regardless of the disease type.

Second, some scholars argue that stricter standards during the examination of patent applications can remove the need for compulsory licenses (Correa, 2006). Although it is not at all clear how this can happen, some developing countries have taken steps to make their IPR systems accessfriendly. For instance, to fight against 'evergreening', the Indian IPR framework wards off patents for new forms or uses of existing pharmaceutical products that are simply minor modifications of existing products, unless they demonstrate improved efficacy (Rajkumar \& Kesselheim, 2013). Other developing countries, such as Argentina and the Philippines, have amended their IPR regulations to restrict the patentability of certain categories of pharmaceutical inventions (e.g., polymorphs, formulations, and additional uses of existing compounds) to avoid granting undeserved patents that can be detrimental to access to lifesaving medicines (Amin \& Kesselheim, 2012).

Third, it is difficult to identify and unravel the impact pathways of compulsory licenses, as information is simply not available. Analysis of 11 out of the 24 compulsory licensing events is not based on official sources at all. Also, as discussed in the limitations, there are at least other 50 compulsory licensing events for which no price data could be retrieved. As the compulsory license is a governmental instrument, our findings call for more transparency vis-à-vis its application and impact. If no price data are ever published, it is simply not possible to assess the effectiveness of this policy tool. Therefore, official information on prices preand post-compulsory licensing should be disclosed to prevent misuse and to ensure that private interests are not put before public interests.

Fourth, industrial polices for creation and accumulation of technological capabilities in development and production of pharmaceutical products in developing countries are needed. As discussed, compulsory licensing itself can be a 'window of opportunity' for this purpose.

\section{CONCLUSION}

Compulsory licensing is often invoked as a panacea for the constraints imposed by TRIPS to ensure access to needed patented medicines during times of health crises. In this regard, the objective of the present paper was to review the existing evidence on the impact of compulsory licensing events in order to assess its utility as an instrument to improve access.

In our systematic review, we verified a mean price reduction between 66.2 and $73.9 \%$ for the 24 compulsory licensing events for which price data are available. Therefore, it would seem that compulsory licensing is indeed an effective mechanism for price reduction with increased availability. However, this result is modulated by the evaluation that it is not clear if compulsory licensing is the most effective alternative to make patented 
medicines more affordable. Nevertheless, it is still the only mechanism available to many developing countries without manufacturing capabilities in pharmaceuticals.

What about the effectiveness of compulsory licenses as an instrument to improve access to medicines in the future? This is a moot question. It makes sense for a government to issue a compulsory license to procure a branded drug for a health crisis only if there are alternative existing generic producers or potential generic producers of the same. The latter could be national companies or a set of actors (e.g., a consortium with universities, public laboratories, investors, public agencies, and firms) in the national innovation system, which can re-engineer and manufacture the required drug in sufficient quantities. Thus, the future of compulsory licensing as an instrument of increasing access to medicines will be shaped by the evolution of two factors. First, under crisis situations, TRIPS has made the window of opportunity for generic producers to supply the rest of the world with drugs under patent, not only much smaller, but much more difficult to even open, given the cumbersomeness of the Paragraph 6 system. In the future, if there are other health crises, and activists force further refinements, this may change. Second, new drugs may be biologics in which emerging countries have an enormous technological (and often regulatory) retard. In such cases, if no alternative sources to a patent drug are available, a compulsory license will serve no purpose.

Thus, in the long run, the best option for developing countries seems to be to build bargaining strength through investment in improving scientific, technological, and innovation capabilities in pharmaceuticals. The ability of governments to negotiate prices or even issue compulsory licenses is likely to be very limited if the

\section{REFERENCES}

Amin, T., \& Kesselheim, A. S. 2012. Secondary patenting of branded pharmaceuticals: A case study of how patents on two HIV drugs could be extended for decades. Health Affairs, 31(10): 2286-2294. https://doi.org/10.1377/hlthaff.2012. 0107.

Babovic, S., \& Wasan, K. M. 2011. Impact of the trade-related aspects of intellectual property rights (TRIPS) agreement on India as a supplier of generic antiretrovirals. Journal of Pharmaceutical Sciences, 100(3): 816-821. https://doi.org/ 10.1002/jps.22326.

Baker, B. 2020. Gilead remdesivir licenses: Half measures are not nearly good enough. Health GAP (Global Access Project). https://healthgap.org/gilead-remdesivir-licenses-halfmeasures-are-not-nearly-good-enough/. technological capabilities of their country are underdeveloped. This is even more extreme in the case of biologicals, for which the technological competence is concentrated in developed countries, mostly in companies that also manufacture innovative products. This calls for entrepreneurial state interventions towards technological capacity and promotion of innovative models for drug development, production, and distribution. The use of compulsory licensing as an industrial policy instrument can be an important trigger of such a process of technological capacity building. For this, nevertheless, it is important to have other instruments and mechanisms to ensure competitiveness and compliance with safety and quality standards.

\section{NOTES}

${ }^{1}$ It is worth mentioning that compulsory licenses can also be used to improve access to drugs due to reasons other than solely affordability. For instance, in 2001, motivated by terrorist attacks using anthrax, the United States considered the use of a compulsory license to ensure the availability of Ciprofloxacin (Ooms \& Hanefeld, 2019). A similar move was observed in 2005, when the United States was concerned about the availability of Tamiflu from the patent owners if confronted with an avian flu pandemic (Love, 2007).

${ }^{2}$ The Medicines Patent Pool was established in 2010 to improve access to low-cost generic versions of patented medicines in low- and middle-income countries through the negotiation of voluntary licences with pharmaceutical companies and other patent holders.

Beall, R. F., \& Kuhn, R. 2012. Trends in compulsory licensing of pharmaceuticals since the doha declaration: A database analysis. PLoS Medicine, 9(1): e1001154. https://doi.org/10. 1371/journal.pmed.1001154.

Beall, R. F., Kuhn, R., \& Attaran, A. 2015. Compulsory licensing often did not produce lower prices for antiretrovirals compared to international procurement. Health Affairs, 34(3): 493-501.

Bognar, C. L. F. B., Bychkovsky, B. L., \& de Lopes, G. D. 2016. Compulsory licenses for cancer drugs: Does circumventing patent rights improve access to oncology medications? Journal of Global Oncology, 2(5): 292-301. https://doi.org/10.1200/ JGO.2016.005363. 
Boseley, S. 2020. US secures world stock of key Covid-19 drug remdesivir. The Guardian. https://www.theguardian.com/usnews/2020/jun/30/us-buys-up-world-stock-of-key-covid-19drug.

Boulet, P., Perriens, J., Renaud-Théry, F., \& Velasquez, G. 2000. Pharmaceuticals and the WTO TRIPS Agreement: Questions and Answers. UNAIDS/WHO. http://apps.who.int/medicinedocs/ pdf/whozip18e/whozip18e.pdf.

Cappuyns, P., \& Vanherpe, I. 2018. The Scoop from Europe: A Licence! And Quick! Recent Developments Concerning Compulsory Licences for Patented Pharmaceuticals in the European Union.

Chakrabarti, G. 2015. Impact and significance of compulsory licensing for access to medicine. International Journal of Intellectual Property Management, 8(3/4): 172. https://doi. org/10.1504/IIIPM.2015.076542.

Chami, G., \& Wasswa-Kintu, S. 2011. Compulsory licensing of generic drugs remains mired in quagmires. Canadian Medical Association Journal, 183(11): E705-E706. https://doi.org/10. 1503/cmaj.109-3898.

Chaudhuri, S., Park, C., \& Gopakumar, K. M. 2010. Five years into the product patent regime: India's response. United Nations Development Programme (UNDP). https://www.undp.org/ content/dam/india/docs/five_years_into_the_product_ patent_regime_india\%e2\%80\%99s_response.pdf.

Chung, J. 2017. Special issue on therapeutic antibodies and biopharmaceuticals. Experimental \& Molecular Medicine, 49(3): e304. https://doi.org/10.1038/emm.2017.46.

Correa, C. M. 2006. Pharmaceutical inventions: When is the granting of a patent justified? International Journal of Intellectual Property Management, 1(1): 4-21.

Diependaele, L., Cockbain, J., \& Sterckx, S. 2018. Similar or the same? Why biosimilars are not the solution. The Journal of Law, Medicine \& Ethics, 46(3): 776-790. https://doi.org/10.1177/ 1073110518804241.

Dowlat, H. A., Kuhlmann, M. K., Khatami, H., \& AmpudiaBlasco, F. J. 2016. Interchangeability among reference insulin analogues and their biosimilars: Regulatory framework, study design and clinical implications. Diabetes, Obesity \& Metabolism, 18(8): 737-746. https://doi.org/10.1111/dom.12676.

Ecks, S. 2008. Global pharmaceutical markets and corporate citizenship: The case of Novartis' anti-cancer drug Glivec. BioSocieties, 3(2): 165-181.

Ford, N., Wilson, D., Chaves, G. C., Lotrowska, M., \& Kijtiwatchakul, K. 2007. Sustaining access to antiretroviral therapy in the less-developed world: Lessons from Brazil and Thailand. AIDS, 21(Suppl 4): S21-S29. https://doi.org/10. 1097/01.aids.0000279703.78685.a6.

Gehl Sampath, P. 2005. Economic aspects of access to medicines after 2005: Product patent protection and emerging firm strategies in the Indian pharmaceutical industry. http:// wwwlive.who.int/entity/intellectualproperty/studies/ PadmashreeSampathFinal.pdf.

Gervais, D. J. 2003. The TRIPS agreement: Drafting history and analysis. London: Sweet \& Maxwell.

Gold, E. R., \& Morin, J.-F. 2012. Promising trends in access to medicines. Global Policy, 3(2): 231-237. https://doi.org/10. 1111/j.1758-5899.2011.00110.x.

Guennif, S., \& Ramani, S. V. 2012. Explaining divergence in catching-up in pharma between India and Brazil using the NSI framework. Research Policy, 41(2): 430-441. https://doi.org/ 10.1016/j.respol.2011.09.005.

Hannah, E. N. 2011. NGOs and the European Union: Examining the power of epistemes in the EC's TRIPS and access to medicines negotiations. Journal of Civil Society, 7(2): 179-206. https://doi.org/10.1080/17448689.2011.573669.

Hason, A. K., \& Shimotake, J. E. 2006. Recent developments in Patent Rights for Pharmaceuticals in China and India Global Interdependence and International Commercial Law: International Law Students Association: Fall Conference 2005. Pace International Law Review, 18(1): 303-316.
Houldsworth, A. 2020. The key covid-19 compulsory licensing developments so far|IAM. IAM Media. https://www.iammedia.com/coronavirus/the-key-covid-19-compulsorylicensing-developments-so-far.

Jesson, J., Matheson, L., \& Lacey, F. M. 2011. Doing your literature review: Traditional and systematic techniques. Thousand Oaks: Sage.

Kale, D., \& Little, S. 2007. From imitation to innovation: The evolution of $R \& D$ capabilities and learning processes in the indian pharmaceutical industry. Technology Analysis \& Strategic Management, 19(5): 589-609. https://doi.org/10.1080/ 09537320701521317.

Konde, V. 2016. Recent developments in compulsory licensing of pharmaceutical patents in India. Journal of Commercial Biotechnology. https://doi.org/10.5912/jcb733.

Loi $n^{\circ}$ 2020-290 d'urgence pour faire face à l'épidémie de covid19, Loi $\mathrm{n}^{\circ} 2020-290$, NOR: PRMX2007883Z. 2020. https:// www.senat.fr/application-des-lois/pjl19-376.html.

Love, J. P. 2007. Recent examples of the use of compulsory licenses on patents. Knowledge Ecology International, 8.

Luca, C. D. 2015. Medicine patent pool-pharma philanthropy or PR? Expert Opinion on Therapeutic Patents, 25(11): 12231227. https://doi.org/10.1517/13543776.2015.1075004.

Manu, T. 2015. Building national initiatives of compulsory licences: Reflecting on the Indian jurisprudence as a model for developing countries. Journal of International Trade Law and Policy. https://doi.org/10.1108/JITLP-07-2014-0015.

Medicines Law \& Policy. 2017. Flow chart tools for TRIPS flexibilities. https://medicineslawandpolicy.org/wp-content/ uploads/2017/05/Flowchart-Tools-MLP.pdf.

Medicines Law \& Policy. 2020. COVID-19 Technology Access Pool (C-TAP): A promising human rights approach. https:// medicineslawandpolicy.org/2020/06/covid-19-technologyaccess-pool-c-tap-a-promising-human-rights-approach/.

Mohara, A., Yamabhai, I., Chaisiri, K., Tantivess, S., \& Teerawattananon, Y. 2012. Impact of the introduction of government use licenses on the drug expenditure on seven medicines in Thailand. Value in Health, 15(1): S95-S99. https://doi.org/10.1016/j.jval.2011.11.016.

OECD. 2020. Treatments and a vaccine for COVID-19: The need for coordinating policies on $R \& D$, manufacturing and access (OECD Policy Responses to Coronavirus (COVID-19)). Organisation for Economic Co-operation and Development. https:// www.oecd.org/coronavirus/policy-responses/treatments-anda-vaccine-for-covid-19-the-need-for-coordinating-policies-onr-d-manufacturing-and-access-6e7669a9/.

Oh, C. 2006. Compulsory licences: Recent experiences in developing countries. International Journal of Intellectual Property Management, 1(1/2): 22. https://doi.org/10.1504/IJIPM. 2006.011020.

Ooms, G., \& Hanefeld, J. 2019. Threat of compulsory licences could increase access to essential medicines. BMJ. https://doi. org/10.1136/bmj.I2098.

Petticrew, M., \& Roberts, H. 2008. Systematic reviews in the social sciences: A practical guide. New York: Wiley.

Prasad, V., \& Babu, P. S. S. K. 2013. Compulsory licensing: Implications on multinational drug companies. International Journal of Intellectual Property Management, 6(4): 247. https:// doi.org/10.1504/IJIPM.2013.057621.

Rajkumar, R., \& Kesselheim, A. S. 2013. Balancing access and innovation: India's supreme court rules on imatinib. JAMA, 310(3): 263-264. https://doi.org/10.1001/jama.2013.7336.

Raju, K. D. 2017. Compulsory v voluntary licensing: A legitimate way to enhance access to essential medicines in developing countries. Journal of Intellectual Property Rights. Scopus. https://www.scopus.com/inward/record.uri?eid=2-s2.0$85018280228 \&$ partnerID $=40 \& \mathrm{md} 5=$

3d276f5bcd26b1d9e6bfc6cda929d0c6.

Ramani, S. V., \& Mukherjee, V. 2014. Can breakthrough innovations serve the poor (bop) and create reputational 
(CSR) value? Indian case studies. Technovation, 34(5-6): 295305.

Ramani, S. V., \& Urias, E. 2015. Access to critical medicines: When are compulsory licenses effective in price negotiations? Social Science and Medicine, 135: 75-83. https://doi.org/10. 1016/j.socscimed.2015.04.023.

Ramani, S. V., \& Urias, E. 2018. When access to drugs meets catch-up: Insights from the use of CL threats to improve access to ARV drugs in Brazil. Research Policy, 47(8): 1538-1552. https://doi.org/10.1016/j.respol.2018.05.008.

Rees, V. 2020. Mylan partners with Gilead to expand access to remdesivir. European Pharmaceutical Review. https://www. europeanpharmaceuticalreview.com/news/119469/mylanpartners-with-gilead-to-manufacture-remdesivir-potentialcovid-19-treatment/.

Rodrigues, W. C. V., \& Soler, O. 2009. Compulsory licensing of efavirenz in Brazil in 2007: Contextualization. Revista Panamericana de Salud Pública, 26(6): 553-559. https://doi.org/10. 1590/S1020-49892009001200012.

Sanders, B. 2005. https://www.sanders.senate.gov/download/ 051215-letter $/$ ? inline=file.

Saroha, S., Kaushik, D., \& Nanda, A. 2015. Compulsory licensing of drug products in developing countries. Journal of Generic Medicines: The Business Journal for the Generic Medicines Sector, 12(3-4): 89-94. https://doi.org/10.1177/ 1741134313503827.

Scherer, F., \& Watal, I. 2002. Post-TRIPS options for access to patented medicines in developing countries. Journal of International Economic Law 5: 913-939.

Son, K.-B., \& Lee, T.-J. 2018. Compulsory licensing of pharmaceuticals reconsidered: Current situation and implications for access to medicines. Global Public Health, 13(10): 1430-1440. https://doi.org/10.1080/17441692.2017.1407811.

Stirner, B., \& Thangaraj, H. 2013. Learning from practice: Compulsory licensing cases and access to medicines. Pharmaceutical Patent Analyst, 2(2): 195-213. https://doi.org/10. 4155/ppa.12.91.

't Hoen, E. 2020a. Covid-19 and the comeback of compulsory licensing|Medicines Law \& Policy. Medicines Law \& Policy. https://medicineslawandpolicy.org/2020/03/covid-19-andthe-come-back-of-compulsory-licensing/.

't Hoen, E. 2020b. Remdesivir developed country price announced. Medicines Law \& Policy. https:// medicineslawandpolicy.org/2020/06/remdesivir-developedcountry-price-announced/.

't Hoen, E., Berger, J., Calmy, A., \& Moon, S. 2011. Driving a decade of change: HIV/AIDS, patents and access to medicines for all. Journal of the International AIDS Society, 14(1): 15. https://doi.org/10.1186/1758-2652-14-15.
Thanitcul, S., \& Braslow, M. L. 2013. Compulsory licensing of chronic disease pharmaceuticals in Thailand. Thai Journal of Pharmaceutical Sciences, 37: 3.

Uman, L. S. 2011. Systematic reviews and meta-analyses. Journal of the Canadian Academy of Child and Adolescent Psychiatry, 20(1): 57-59.

Urias, E. 2015. Improving access to HIV/AIDS treatment in Brazil: When are compulsory licenses effective in price negotiations? [Doctoral Dissertation, Maastricht University]. http://www. merit.unu.edu/training/theses/urias.pdf.

WTO. 2006. TRIPS and pharmaceutical patents: Obligations and exception. http://www.wto.org/english/tratop_e/trips_e/ factsheet_pharm02_e.htm\#art31.

WTO. 2015. WTO|2015 News items-WTO members agree to extend drug patent exemption for poorest members. https:// www.wto.org/english/news_e/news15_e/trip_06nov15_e. htm.

\section{ABOUT THE AUTHORS}

Eduardo Urias is a postdoctoral researcher and lecturer at the Athena Institute at the VU Amsterdam. His research interests include the impact of intellectual property rights on access to medicines, technological catch-up in biopharmaceuticals, circular economy, integration between science and society and public engagement through science shops and community service-learning, and interand transdisciplinary knowledge integration.

Shyama V. Ramani is Professorial Fellow at UNUMERIT. Her research focuses on the relationships between technology, innovation and their governance for inclusive development. Her work examines the role of technology and innovation in conjunction with actor (government, firms, citizens, public laboratories, NGOs, etc.) engagements to attain the Sustainable Development Goals related to sanitation, sustainable cities and communities, education and climate change.

Publisher's Note Springer Nature remains neutral with regard to jurisdictional claims in published maps and institutional affiliations.

Accepted by Suma Athreye, Area Editor, 28 July 2020. This article has been with the authors for three revisions. 